\section{Temporary dumping syndrome after gastric peroral endoscopic myotomy: should we control the glycemia?}

Gastric peroral endoscopic myotomy (G-POEM) is a new endoscopic technique that involves cutting the pyloric sphincter, with minimal invasiveness compared with the surgical approach [1-3]. The technique can be used to treat post esophagectomy gastric outlet obstruction [4]. Here, we report the case of post esophagectomy outlet obstruction treated with G-POEM but complicated by multiple episodes of post-procedure hypoglycemia.

The patient had undergone esophagectomy in 2004 for the treatment of squamous cell carcinoma and liver transplantation in 2009. He was referred 4 months ago for dysphagia, vomiting, and gastric sensation of heaviness. To minimize his symptoms, he had progressively reduced his food intake and, consequently, had lost $10 \mathrm{~kg}$ in weight. Parenteral nutrition was introduced. The patient was diagnosed with post esophagectomy gastric outlet obstruction and G-POEM was planned.
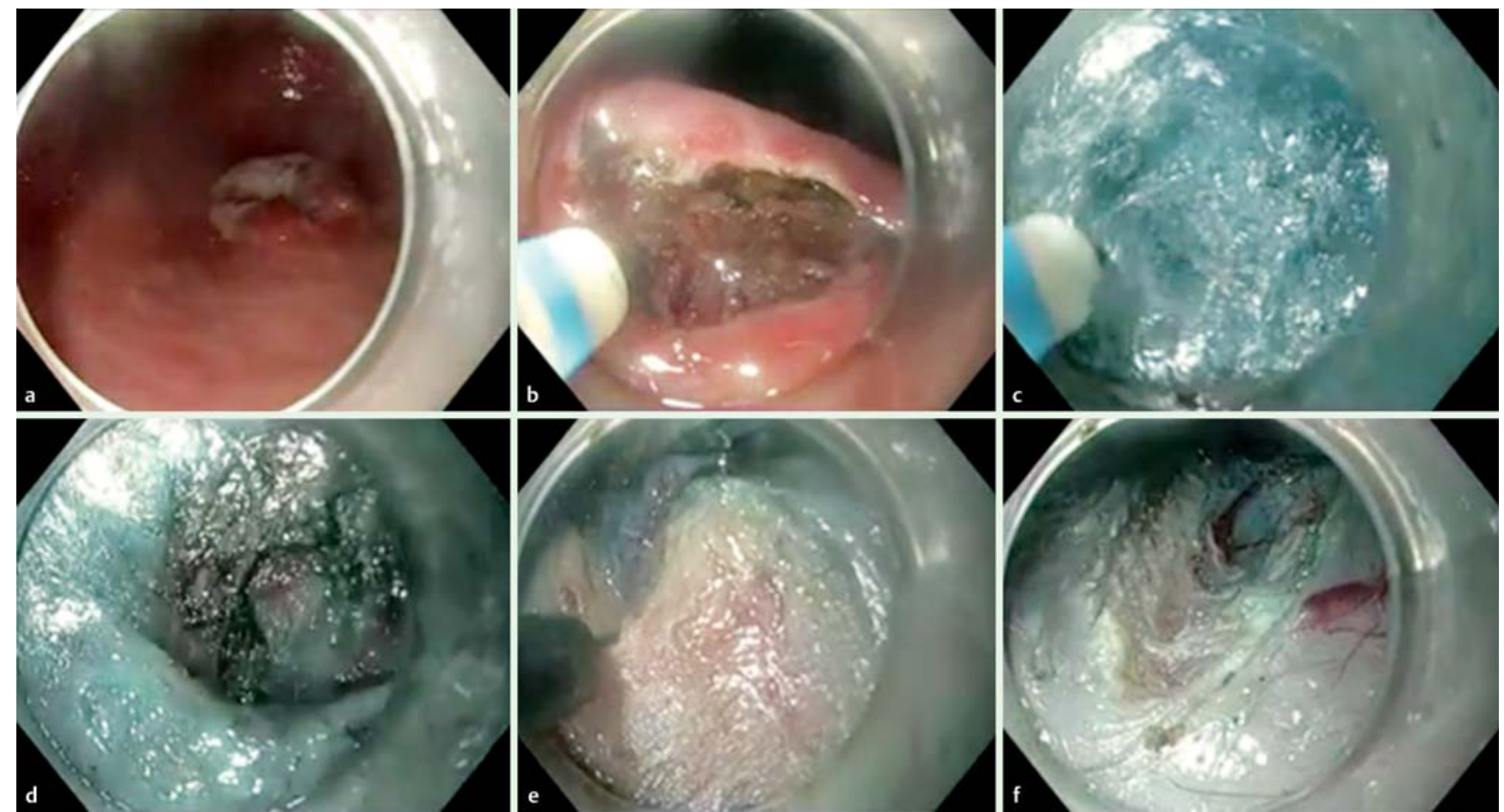

Fig. 1 Gastric peroral endoscopic myotomy procedure. a Endoscopic view of the pylorus before the myotomy. b Mucosal incision. c Submucosal tunneling. d View of the pylorus muscle in the tunnel. e Myotomy using a HookKnife. $\mathbf{f}$ View of the final myotomy. was educated on the need to take complex carbohydrate snacks rather than sugary snacks.

After discharge, the patient was monitored and only two new hypoglycemia episodes occurred (Day 7 and Day 20). These early evaluations showed that G-POEM was effective for the initial resolution of symptoms, with no further dysphagia, gastric heaviness, or vomiting experienced.

G-POEM is a new effective option for the treatment of gastric obstruction, but glycemia should be monitored to ensure early detection of dumping syndrome in the days following the procedure. This syndrome can be controlled easily by educating the patient on ways to reduce glucose spikes.

\section{Endoscopy_UCTN_Code_CPL_1AJ_2AI}

Competing interests: None

\section{Typhaine Louazon', Jérome Rivory', Sabine Roman 2,3, François Mion², Thierry Ponchon ${ }^{1,3}$, Mathieu Pioche ${ }^{1,3}$}

1 Department of Endoscopy and Gastroenterology, Edouard Herriot Hospital, Lyon, France

2 Digestive Physiology, Hospices Civils de Lyon and Lyon I University, Lyon, France 3 INSERM U1032, LabTau, Lyon, France 


\section{References}

1 Chung H, Dallemagne B, Perretta $S$ et al. Endoscopic pyloromyotomy for postesophagectomy gastric outlet obstruction. Endoscopy 2014; 46 (Suppl. 01): E345-346

2 Gonzalez J-M, Vanbiervliet G, Vitton $V$ et al. First European human gastric peroral endoscopic myotomy, for treatment of refractory gastroparesis. Endoscopy 2015; 47 (Suppl. 01): E135 - 136

3 Khashab MA, Stein E, Clarke JO et al. Gastric peroral endoscopic myotomy for refractory gastroparesis: first human endoscopic pylo- romyotomy (with video). Gastrointest Endosc 2013; 78: 764-768

4 Chaves DM, de Moura EGH, Mestieri LHM et al. Endoscopic pyloromyotomy via a gastric submucosal tunnel dissection for the treatment of gastroparesis after surgical vagal lesion. Gastrointest Endosc 2014; 80: 164

5 Malik S, Mitchell JE, Steffen K et al. Recognition and management of hyperinsulinemic hypoglycemia after bariatric surgery. Obes Res Clin Pract 2015. DOI: 10.1016/j. orcp.2015.07.003

\section{Bibliography}

Dol http://dx.doi.org/

10.1055/s-0041-111027

Endoscopy 2016; 48: E10-E11

(C) Georg Thieme Verlag KG

Stuttgart · New York

ISSN 0013-726X

\section{Corresponding author}

\section{Mathieu Pioche, MD}

Endoscopy unit - Digestive Disease Department Pavillon L - Edouard Herriot Hospital 69437 Lyon CEDEX

France

Fax: +33-4-72110147

mathieu.pioche@chu-lyon.fr 